\title{
Water Scarcity in Wetland Area within Kandi Block of West Bengal: A Hydro-Ecological Assessment
}

\author{
${ }^{1}$ Swadesh Pal and ${ }^{20}$ Osondu C. Akoma
}

\begin{abstract}
Water logging areas are basically designated by water affluences in permanent or seasonal basis. But due to accelerated rate of human intervention and human induced modification of natural processes, natural wetland landscapes also have today under acute seasonal water scarcity. Wetland areas have been gradually squeezing, permanent wetland areas have transmuted into semi permanent wetlands with groundwater table (GWT) slashing down rapidly. Due to intensive boro culture, as much as 2444 mini deeps ground water table have been slashed by $0.32 \mathrm{~m}$./ year since 1968 to 2008 during summer but it is more higher (0.35 m./year) between 2001-2008. During May, 1968 G.W.T. depth was $6.09 \mathrm{~m}$. whereas it is almost $20.19 \mathrm{~m}$ by 2008. Changes in land use to some extent mitigate such ensuing threats of ground water scarcity as a result the entire hydrological and ecological scenario of the wetland landscape has under gone massive negative transformation.

Key words: Wetland, water scarcity, hydro-ecology, human invasion, lowering of ground water table, clogging of tributary
\end{abstract}

\section{Introduction}

The term 'wetland' describes a habitats representing a variety of shallow, vegetated systems, such as bogs, marshes, swamps, floodplains, coastal lagoons, estuaries, coral reefs and seagrass beds, where the shallowest sites are often transitional areas and can be seasonally or intermittently flooded (Groombridge and Jenkins, 1998). Though it may be hard to fathom, water scarcity in wetland area is a possibility and a prevalent event in almost the entire deltaic wetland areas of West Bengal, especially wetland areas of Kandi block of Murshidabad district. Wetland (also called beel in local language) is defined as the interface between terrestrial land and aquatic landscape. Wetlands are the areas of marsh, fen, peat land or water, whether natural or artificial, permanent or temporary, with water that is static or flowing, fresh, brackish or salt, including areas of marine water, the depth of which at low tide does not exceed six meters (IUCN, 1979). Wetlands generally include swamps, marshes, bogs and similar areas (Mitch and Gosselink, 1986). Some unique characteristics of wetland in this regard include presence of water either seasonal or permanently, soil saturation, presence of aquatic vegetations or hydrophytes and hydric soil. Given high population densities, increased rates of deforestation (particularly in Indonesia) and the large degree of ecosystem fragmentation in India, which has more than 4,000 dams, Southeast Asia's wetlands are probably the most degraded in the world. This is reflected in the rapid decrease or local extinction of large grazing wetland species, such as the Indian rhinoceros (Rhinoceros unicornis) and swamp deer (Cervus duvauceli, C. eldi, C. schomburgki), and the high number of globally threatened fish, amphibians, water turtles and bird species in the region (Burke et al., 2001; IUCN, 2003a; IUCN et al., 2004). In recent years, there has been increasing awareness of the fact that natural wetlands provide many valuable functions like flood alleviation, groundwater recharge, retention and regulation of pollutants, refuge for fish and other fauna etc. (Bugenyi, 2001; Owor, et al., 2007)

Utilization of water from these wetland areas has proceeded without a basic understanding of the hydroecological system of the system which on the long run has resulted in water scarcity. About $6 \%$ of the geographical land of the earth surface falls within wetland areas (MoEF, 1992). Large sections of people are directly or indirectly dependent on wetland

1 Department of Geography Visva-Bharati, Santiniketan, West Bengal, India. swadeshpal82@yahoo.in

${ }^{2}$ Department of Biology Bahir Dar University, Ethiopia. 
areas for their livelihood and sustenance. However, the fast growing population has induced land degradation and increased abstraction of water and a critical problem in water resources management (Rutledge and Daniel, 1994; Dagnachew, et al., 2003; Temalem, 2002). Each unit of wetland has its multifarious function and usefulness involving various aspects in human life and activities. Unfortunately about $50 \%$ of the total wetland areas today have been subjected to negative transformation and degradation. Owing to such negative transformation, wetlands in India are currently under serious threats of extinction. Various threats were categorized and their incidence in about 147 wetlands, listed in the Directory of Indian Wetlands (1993). Accordingly the assessment of the hydrological behavior of inflowing rivers and the temporal and spatial variation of river flows is vital as the rivers are interconnected with the complex and delicate wetland ecosystem and the rivers being partly the source of recharge for the aquifers (Tenalem, 2008).

In the present study a number of wetland areas like Chorki, Bagdasha, Sapmara (collectively known as Hizole beel) and Amal bandha, Ghatahari, Madgarya, Parulia etc. (collectively known as Kumarsanda beel) make up the Kandi block. Large number of significant rivers like Dwarka, Babla, Mayurakshi, Kuya, Banki have made the region of significant hydrological importance. But today due to various forms of human interference in these wetland areas there is acute water shortage resulting in seasonal water scarcity. Such scarcity of water is not only precarious from hydrological point of view and requires serious institutional concern but from ecological stand point needs to be mitigated. An important new study on variability in the role of wetlands was carried out by Bullock and Acreman (2003), wherein they assess the differences in wetland water quantity functions based on 169 worldwide studies conducted from 1930 to 2002. They proposed a more scientifically defensible functional assessment system (of wetlands) by establishing a benchmark for the aggregated knowledge of wetland influences upon downstream river flows and aquifers. They recommend that future water management actions for both basins and aquifers carefully evaluate each wetland's characteristics as they will exhibit different performance and functional roles according to their location in the watershed, their climate, and the extent of other development features.

\section{Location of the Study Area}

Kandi Block is one of the largest units of Murshidabad district covering an area of $240.43 \mathrm{~km}^{2}$. It consists of 10 Gram Panchayats (G.P.) and 1 municipality (Kandi) and 101 rural settlements and 93 villages. It is located between latitude $23^{\circ} 54^{\prime} 34^{\prime \prime}$ North to $24^{\circ} 07^{\prime} 08^{\prime \prime}$ North and longitude $87^{\circ} 59^{\prime} 09^{\prime \prime}$ East to 88¹1'37" East.

\section{Present Hydro-Geographical and Ecological Condition of the Area}

A large part of Kandi Block has some impacted moribund seasonal wetlands with recurring flood. The topography of the area ranges from 14 m.a.s.l to 30 m.a.s.l (fig. 1). A narrow tract of Gokarna along Dwarka River and most part of the Kumarsanda and Hizole area (known as Hizole wetland) are depressed land. There are pockets of depressed, seasonal, marsh land scattered within the stable area. Average slope is less than 1 inch per $5280 \mathrm{~m}$ (1 foot per mile); slope direction toward north/south and south/east. A number of significant rivers like Dwarka, Babla, Mayurakshi, Kuya, Banki and other small streams intersect in this block forming an anastomosing network of rivers in the Hizole wetland area. Observed soil types are clayey and clay loam. The geological composition of the area comprises of almost flat flood plains with both older and younger alluvium. Annual average rainfall ranges from $1490 \mathrm{~mm}$ to 1550 $\mathrm{mm}$. About $82.85 \%$ of the total rainfall is recorded within monsoon period (June to October) and coefficient of variation of monthly rainfall strongly ranges from $95 \%$ to $138.28 \%$ during last 10 years. About a hundred and fifty years ago most of the wetland areas were covered by under dense grass land, Hizole tree (Barringtonia acutagula), and several species fishes, amphibians, reptiles and birds with an abundance of both endemic and exotic varieties (Siraj, 1995, District Gazetteer, 2003). The objectives of this research are to: study spatial and temporal change of wetland area and its intrinsic and extrinsic hydrology and ecology; investigate spatio-temporal 
changeover of sub-surface water condition of the study area and; determine the basic causes for changes in surface and sub surface water condition and ecological metamorphism.

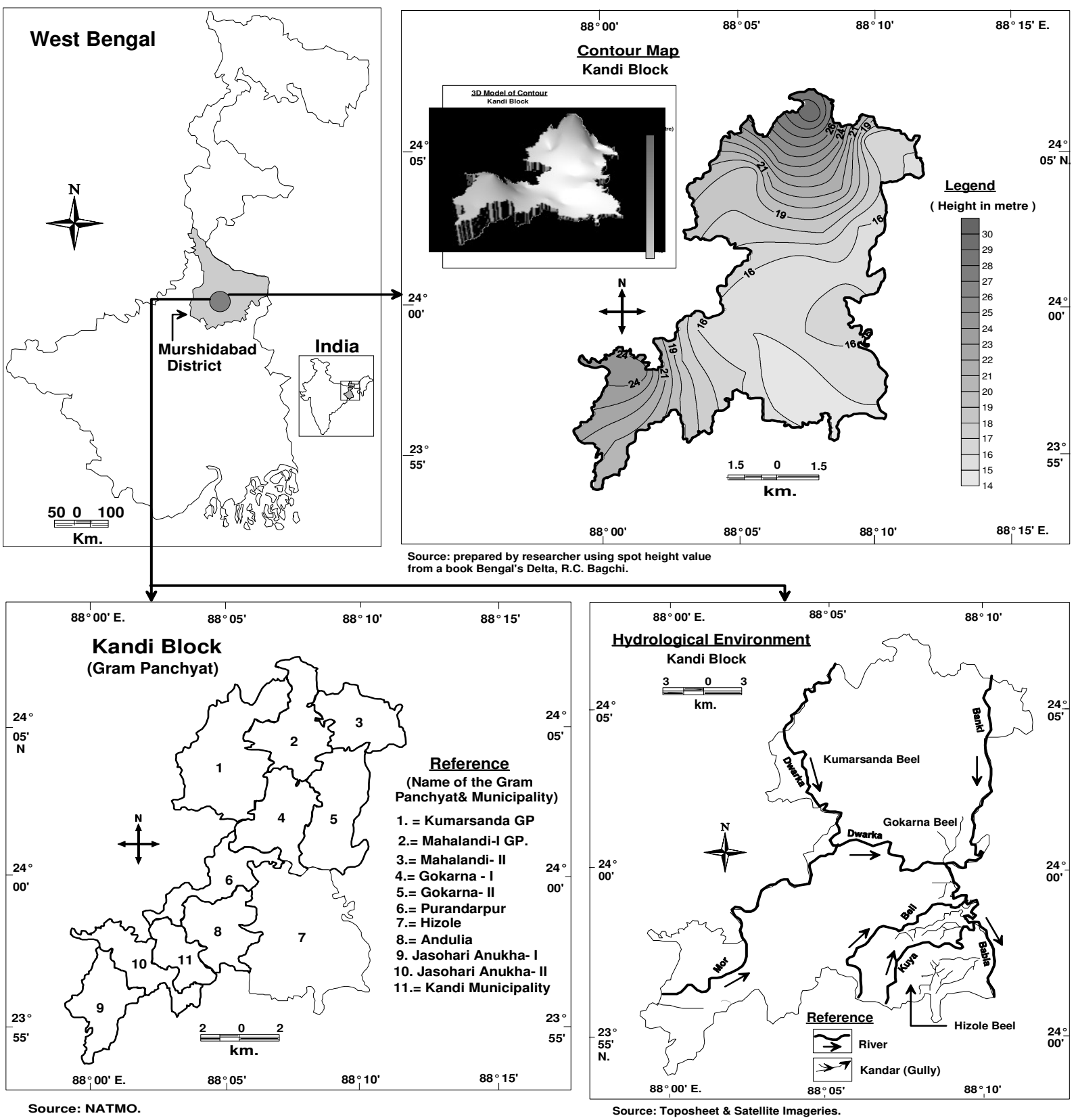

Fig. 1Maps of West Bengal showing the study area of Kandi Block 


\section{Methodology}

The study is based on both primary field observation and secondary data. The primary data obtained from present ground water samples collected with cordial cooperation of farmers and local deep drillers. Ground Water Table (GWT) measurements of 31 selected deeps were taken, where both monsoon and pre-monsoon water table account have been made. Secondary data e.g. rainfall data, evaporation data were collected from Kandi Meteorological Office. Account of mini deeps were collected from Electric Supply Office, Gokorna and Kandi. Total yearly recharge estimation was evaluated using ground water balance equation (Kumar \& Seetapathi, 2002.) and re-modified Chaturvedi's formula by author i.e.

$\mathrm{R}=1.2(\mathrm{p}-13)^{0.5}$

Where, $\quad \mathrm{R}=$ ground water recharge from rainfall during monsoon

$$
\mathrm{p}=\text { mean rainfall in monsoon. }
$$

Discharge value especially during summer season by mini deeps have been calculated multiplying total mini deeps, running days, hours/day and yielding capacity. Water table depth during 1968 was obtained from an old survey report (Sen, 1970). Hydraulic head is calculated on the basis of the spot height of a point minus ground water table( GWT) depth of the same point. Temporal change of spatial extent of wetland, its hydrological character was determined using topographical sheets of SOI and satellite imageries and empirical survey.

\section{Results and Discussion}

\section{Present GWT Status in the Kandi Block} during Monsoon \& Pre-monsoon Period

\section{a) Pre-monsoon Period}

As per the survey of selected 31 mini deep tube-wells during May, 2007-08
GWT ranges from $18.29 \mathrm{~m}$ to $21.94 \mathrm{~m}$. Water table depth is amazingly high in Patna (Mahalandi-I G.P.) followed by Kandi (M) (21.68 m) etc. Water table depth is minimum in Molla (18.29 m) persuaded by Bohara (Anukha-I G.P.) etc. In the Hizole wetland area also GWT is unexpectedly low in spite of having experienced by seasonal water stagnation and flood resurgence. In Srikrishnapur premonsoon GWT is $19.20 \mathrm{~m}$, in Bhawanandapur it is about $20.42 \mathrm{~m}$, about $20.11 \mathrm{~m}$ in Natungram - all these points are found within the Hizole wetland area. Minimal ground water fluctuation was observed in Kumarsanda wetland area with GWT values ranging from $19.51 \mathrm{~m}$. to $20.52 \mathrm{~m}$. Bijaynagar is located just at the fringe of Amal bandha wetland and recorded GWT depth of $19.74 \mathrm{~m}$. Standard Deviation (SD) value (0.87) indicates a fair degree of uniformity of GWT depth and co-efficient of variation $(\mathrm{CV})$ value $(4.32 \%)$ and in the same way supports similar trend of variability.

b) Monsoon period

Spatial GWT depth value ranges from $10.79 \mathrm{~m}$ to $13.84 \mathrm{~m}$ all over the block; with about $22.58 \%$ of the selected places recording GWT values above $13 \mathrm{~m}$. Maximum values were recorded near Nabagram $(13.84 \mathrm{~m})$, Patna $(13.84 \mathrm{~m})$ followed by Motra $(13.78 \mathrm{~m})$, Mahalandi $(13.55 \mathrm{~m})$. Comparatively, the situation is relatively favorable in Srikrishnapur $\left(\begin{array}{ll}10.79 & \mathrm{~m}\end{array}\right)$ Bhawanandapur $(10.79 \mathrm{~m})$ in Hizole area, Bohara $(10.79 \mathrm{~m})$; in Anukha-I, Bijayanagar $(11.38 \mathrm{~m})$ and Kumarsanda area. Large scale intermittent water stagnation for 3 or 4 months during monsoon creates such favorable situation. SD value (0.98) and CV value (8.12\%) shows the reality i.e. spatial level of consistencies are quite scarce in comparison to pre-monsoon season. 

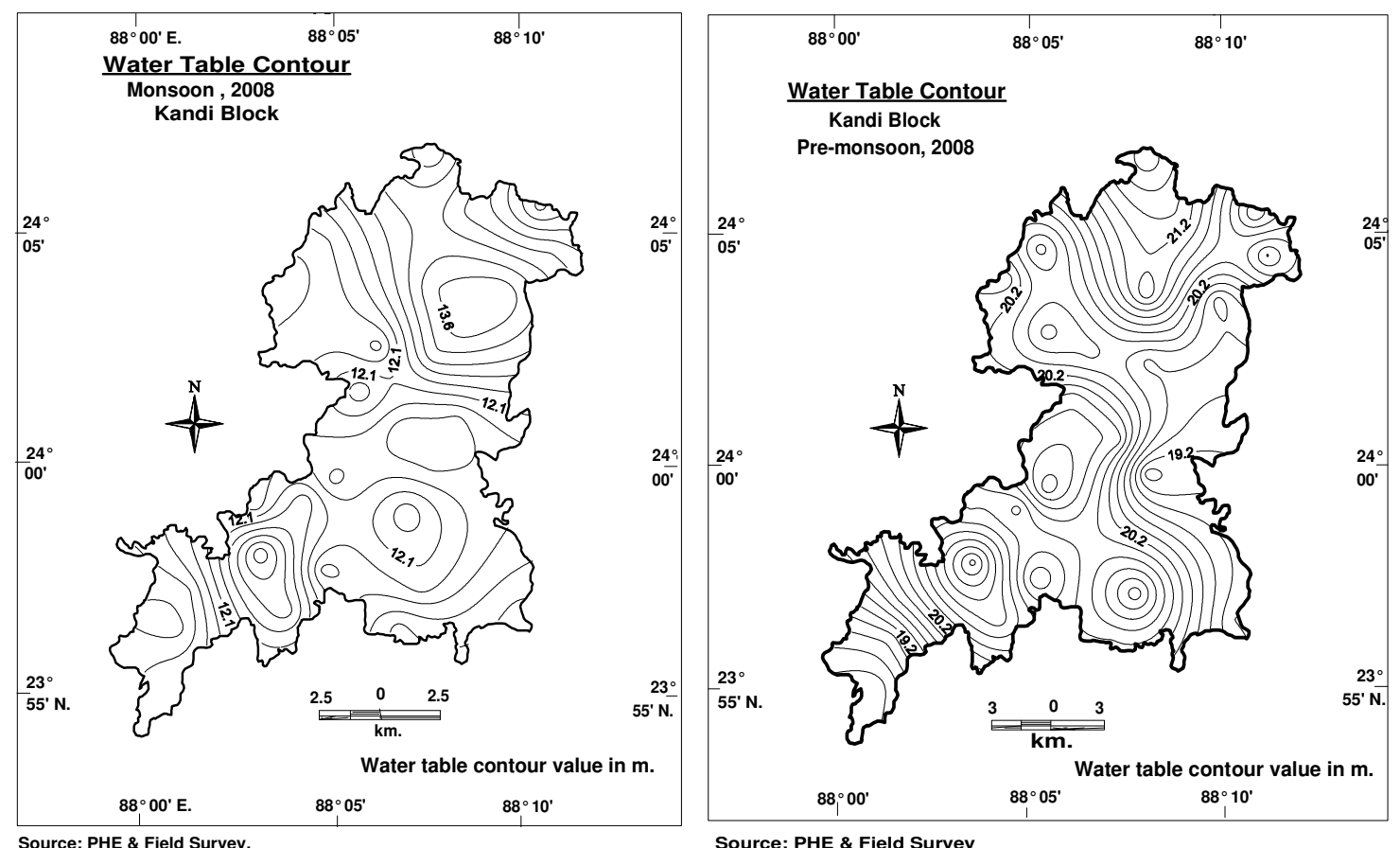

Source: PHE \& Field Survey.

Source: PHE \& Field Survey

Fig. 2 Maps of Kandi Block showing water table contours during Monsoon and Pre-monsoon seasons of 2008

\section{Seasonal Changes of GWT within the Kandi Block}

Seasonal water table fluctuation ranged from $5.66 \mathrm{~m}$. to $9.93 \mathrm{~m}$. From the recorded values about $16.12 \%$ of the mini deeps had seasonal water fluctuation rate above $9 \mathrm{~m}$ and $12.90 \%$ of the mini deeps had water table fluctuation rates below $7 \mathrm{~m}$. Average level of change is about $8.10 \mathrm{~m}$. in absolute figure or $67.95 \%$ in relative configuration. In Hizole area two selected points namely Bhawanandapur $(9.63 \mathrm{~m}$ or $89.24 \%)$ and Aharinagar (9.32 $\mathrm{m}$ or $77.61 \%$ ) recorded exceptionally high GWT fluctuations. Water stagnation during monsoon period and draught period coupled with large ground water abstraction for irrigation purposes are mainly responsible for large scale water fluctuations. In Nabagram (5.66 m or $40.92 \%$ ) and Motara $(6.32 \mathrm{~m}$ or $45.90 \%)$ the seasonal rates of change were relatively low because of less aggressive irrigation practices as well as diversified cropping pattern.

\section{Monthly fluctuation of Ground Water Table}

A close study of water table in Hizole areas shows that there is wide range of water table fluctuation between different months. Here a relationship can be drawn between recharge due to rainfall and discharge due to ground water lifting. As per the study of 2006/2007 years water table depths were highest and thus deepest in the month of May and there was a steady decline of Ground Water Table (GWT) during summer due to massive water drafting. From table 1 it can be surmised that rainfall-recharge relationship is not very strong $(r=0.110$ to 0.132$)$ due to the almost two months lag period. Lag period being the interlude between time of rainfall and recharge response time. Figure 3 presents a graphical representation of rainfallgroundwater table relationship during 2007 sampling period and reveals a consistent trend of decreasing groundwater depth from January to May with a comparatively increasing rising trend in rainfall with the same period. A consistent rise in groundwater depth was recorded from June to a maximum depth in October and a dip in November and December. Rainfall however was highest in July, fluctuated between August and September and generally decreased to December. From this relationship it could be surmised that at peak rainfall in July, groundwater recharge was not immediate but required a lag period of three months to result in a maximum rise in groundwater table in October. 
Table 1: Recharge response due to rainfall during in 2007 and 2008

\begin{tabular}{|l|l|l|l|l|}
\hline Months & Rainfall \& water table in 2007 & \multicolumn{2}{l|}{ Rainfall \& water table in 2008 } \\
\hline & Rainfall $(\mathrm{cm})$ & Water Table $(\mathrm{m})$ & Rainfall $(\mathrm{cm})$ & Water Table $(\mathrm{m})$ \\
\hline January & - & 11.88 & - & 11.12 \\
\hline February & - & 13.25 & 4.56 & 13.48 \\
\hline March & 0.6 & 14.78 & 3.76 & 14.20 \\
\hline April & 3.96 & 17.86 & 3.28 & 18.43 \\
\hline May & 8.24 & 19.81 & 14.18 & 20.57 \\
\hline June & 29.68 & 17.80 & 27.42 & 15.99 \\
\hline July & 66.80 & 14.78 & 57.42 & 13.86 \\
\hline August & 26.82 & 11.03 & 35.81 & 11.73 \\
\hline September & 32.54 & 9.74 & 32.46 & 9.19 \\
\hline October & 3.18 & 7.92 & 4.60 & 6.09 \\
\hline November & 0.58 & 10.05 & 0.26 & 8.68 \\
\hline December & - & 10.36 & - & 10.51 \\
\hline SD & 19.87 & 11.81 & 17.88 & 5.13 \\
\hline CV & $138.37 \%$ & $27.1 \%$ & $116.83 \%$ & $31.03 \%$ \\
\hline r & 0.132 & & 0.110 & \\
\hline
\end{tabular}

Source: Kandi Meteorological Station, PHE Dept. and Field Check.

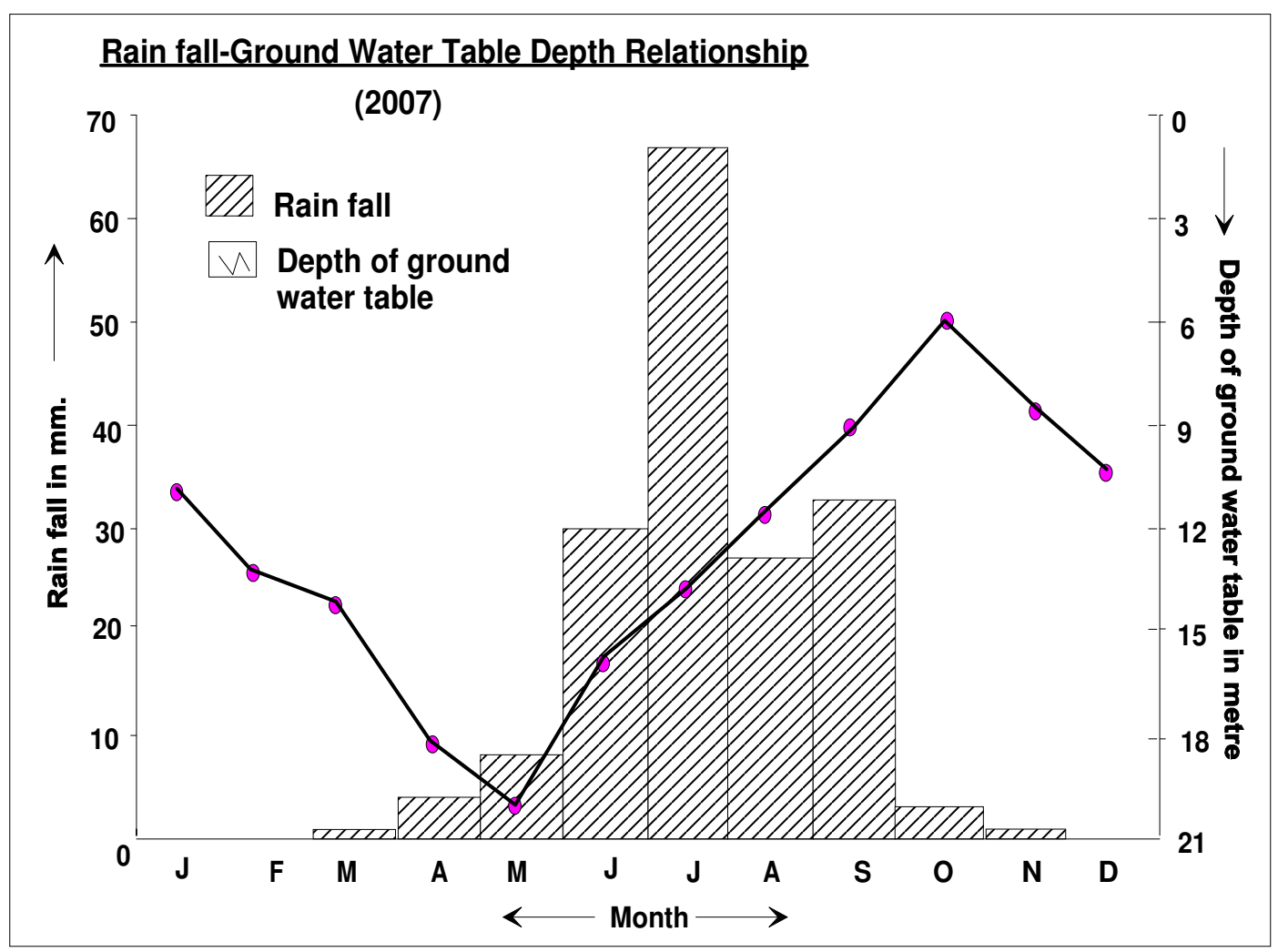

Source: Recorded from a tubewell, Saspara, Kandi.

Fig. 3 Seasonal changes in Rainfall and Groundwater table Depths in Kandi Block in 2007 


\section{Comparative time-line assessment of temporal change of GWT in the Kandi Block}

Figure 4 shows comparative changes in groundwater table recorded during monsoon and premonsoon seasons of 1965 and part of the present study (2008). As reported by Satyakam Sen (1965) in his article "The Importance of Drainage in Agriculture of West Bengal" the average water table depth was $6.09 \mathrm{~m}$; while in the present study average water table depth is about $20.19 \mathrm{~m}$. which is around 330\% lower than 1965's status indicating a more stringent water deficit situation. This fact is further corroborated by the experience of the common people in the area. They observed that in the past during monsoon season water table rose up to near the surface $(2.84 \mathrm{~m}$.) with several ground water upwelling springs whereas recent studies have recorded mean monsoon GWT measurements in the neighborhood $12.07 \mathrm{~m}$ (Fig. 4).

Consequently a number of observed changes have occurred in the fauna, flora and physiognomy of the Kandi Block wetland over time and these include shrinking shrub and grassland especially around Hizole, Munigram and Begampur assuming the status of semi permanent wetlands (Fig. 5). In this period large numbers of fragmented unit were available in the Kumarsanda wetland area. All those areas were semi permanent in this major wetland unit. During 1968-69, Hizole tree dominated wetland area has lost its extensive expanse and squeezed into a small unit as well as become completely semi permanent except Chorki wetlands.

Conversely over time an interestingly large number of fragmented parts of Kumarsanda area coalesced to form some relatively large units giving rise to permanent wetlands due to loss of retention capacity (Fig. 6). Total wetland area during 1916 was 35.05 sq.km, 1968 was 7.43 sq. $\mathrm{km}$ and 8.29 sq. km in 2008. Depth of wetland areas on the average has reduced from $>1.22 \mathrm{~m}$ to $<1.06 \mathrm{~m}$ since 1916 to present period. Natural grassland and Barringtonia (Hizole tree) (Siraj, 1995) shaded parkland like ecotonian ecosystem turned into paddy dominating artificial and fragile ecosystem. Seasonal dynamics of the hydrological character of the beel has intensified many times. Fluctuation of area extension and depth fluctuation of the wetland area have now multiplied. Occurrence of serious floods is now a common event in the area every monsoon.

\section{Causes of Water Scarcity in these Wetland Areas}

Hydromorphic and ecomorphic evolution of the beel area can be explained in light of a number of causal consequences. Earlier studies reported depth of the wetland was considerably high, $>6 \mathrm{~m}$ in some places (W.B. Dist. Gazetteer, 2003) and due to high water retention capacity most of the beels were permanent. Gradual deposition of sand, silt carried by Dwarka, Mayurakshi river systems in haphazard manner fragmented the Hizole beel and Kumarsand beel unit. Consequently the beels lost their retention capacity as per report of O'Malley (1997). At the same time the feeder channels were choked thereby obstructing free flow of water between Dwarka River and beel units except duringpeak monsoon insurgence. Steady obstruction of water from ground water aquifer by wide spread summer paddy cultivation via mini deep tube-well irrigation system is intimately responsible for ground water slashing. Before 1960 there were comparatively fewer shallow tube-wells; but today there are as many as 2444 mini deep tube-wells in this block. Huge rate of abstraction is largely responsible for recharge discharge disparity.

Total water recharge volume is currently $402.50 \times 10^{5}$ cubic meters in Kandi block. Summer period discharge due to water draft by 2444 mini deeps all over the blocks being calculated. As discharge is $58.95 \times 10^{5}$ cubic meters greater than recharge so this amount of water just for summer season cultivation is used from ground storage. In Kumarsanda area the ground water recharge is $10.29 \times 10^{5}$ cubic meters higher than discharge. Hizole area also suffers acute ground water deficiency $\left(-4.1 \times 10^{5}\right.$ cubic meters or $4.56 \%$ greater than ground water recharge). The most acute degree of deficit water balance is noticed in Gokarna-I where irrigational water discharge is $45.37 \%$ greater than annual recharge. 


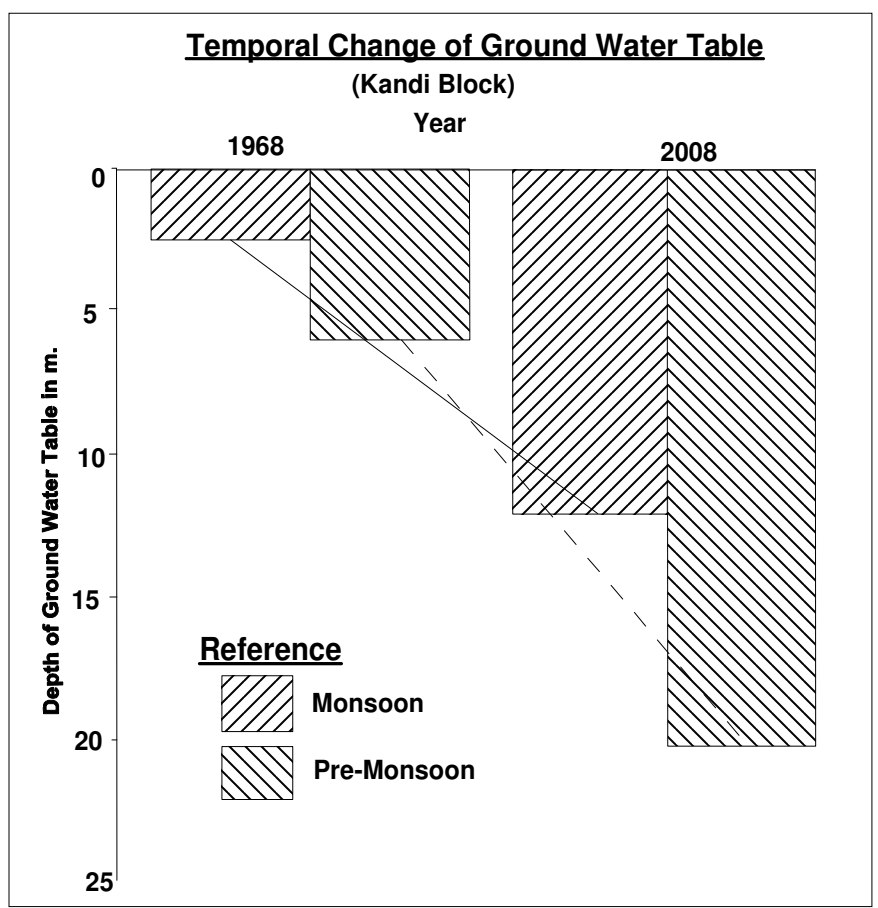

Fig.4 Temporal changes in Groundwater Table in Kandi Block
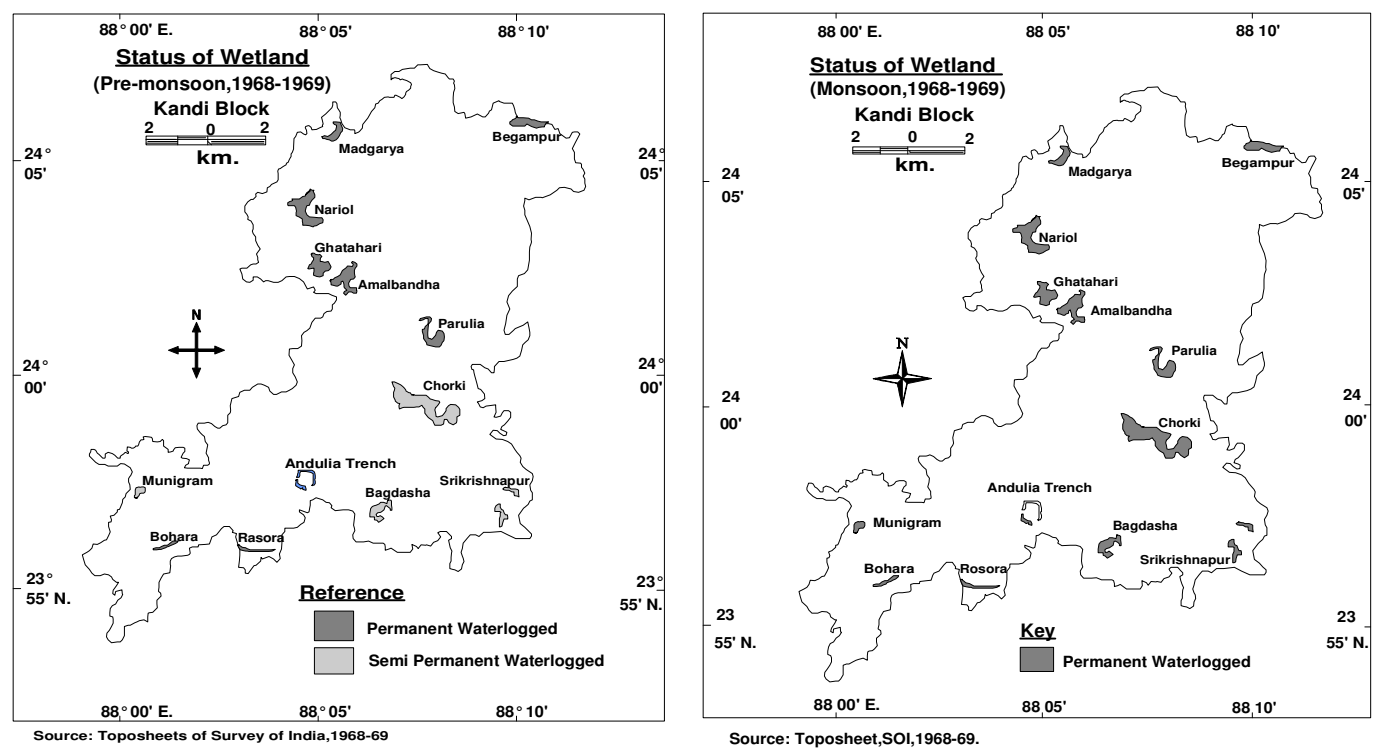

Figure 5a Seasonal changes in status of wetlands over time in Kandi Block 

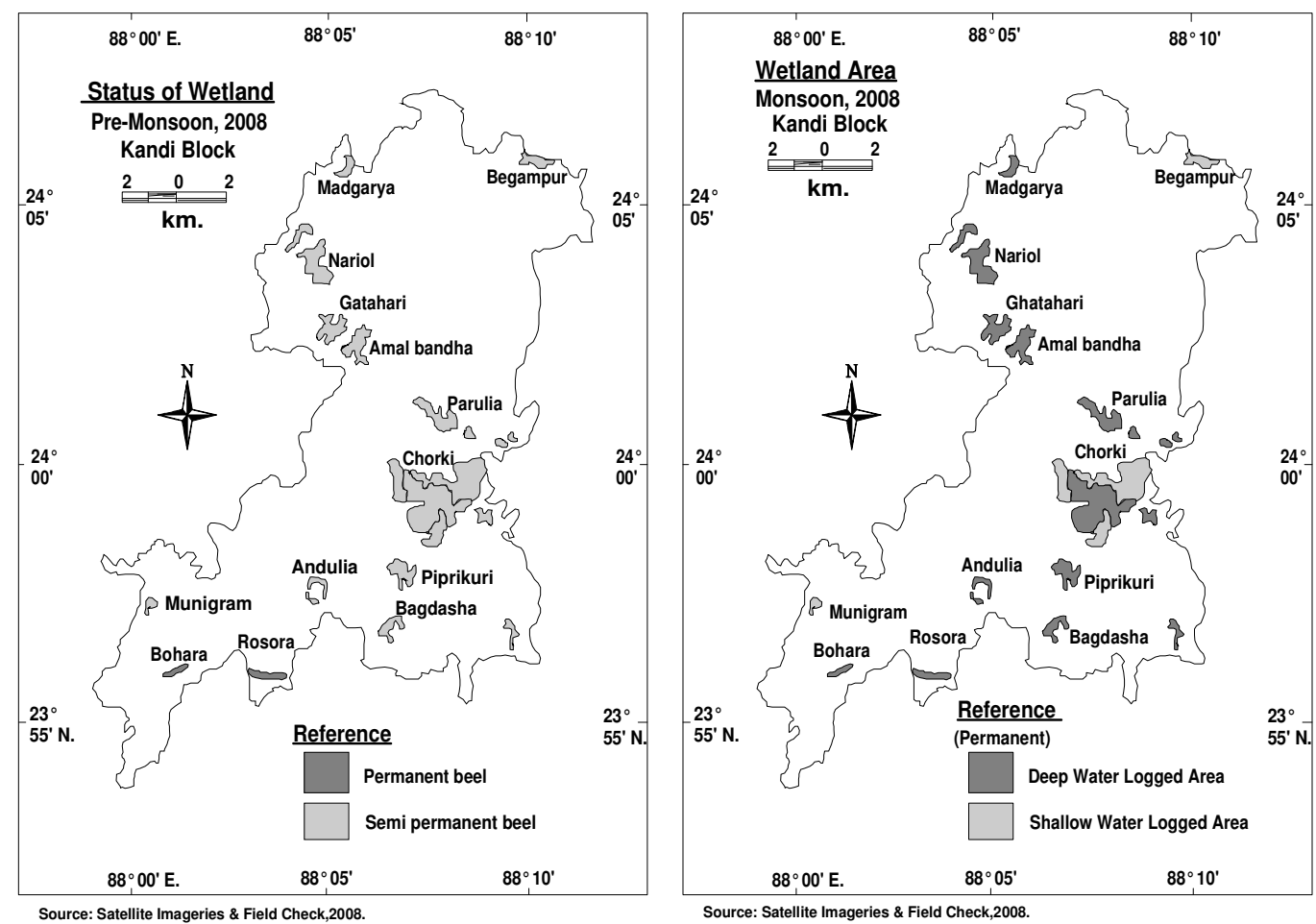

Figure. 5b Seasonal changes in status of wetlands over time in Kandi Block

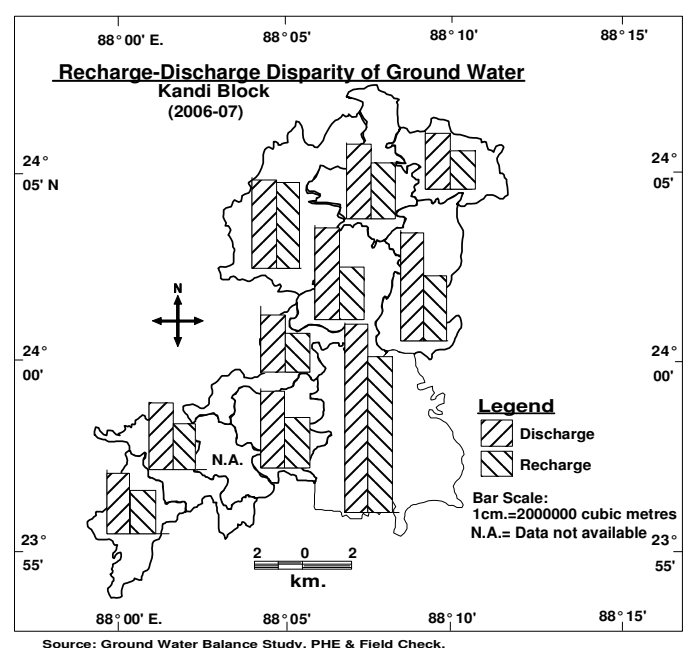

Fig. 6 Disparity between groundwater recharge-discharge rates in Kandi Block 


\section{Relationship Assessment between number of Mini Deep Tube-well and GWT:}

With increasing number of mini deep tube-well crop intensity level is rapidly increasing. Irrigation facilities during summer lead to increased crop productivity by farmers and consequently ground water table is suddenly lowered in all parts of the block area even to the wetland areas.

With respect to entire block, the relationship between number of mini deep tube-well and ground water table depth reveals highly positive co-relation $(r=0.999)$ and highly significant at 0.01 confidence level (See Table 2).

\section{GWT Lowering and Surface-Sub-surface Flow Disparity:}

Surface flow direction is the function of ground slope and slope guided channels, permeability or porosity of soil field moisture deficiency etc. At the same time base flow character is determined by the pond time, pond area, depth of soil layer, nature of soil, evapotranspiration rate, rainfall volume, rain fall concentration characters, geological layer arrangement etc. In case of confined aquifer condition, there is normal flow conformity between surface and sub-surface. But in case of unconfined aquifer condition, there is uncoordinated water flow direction between surface and sub-surface water flow. Under the moribund deltaic zone the surface drainage is extremely complicated due association of large number of river and gully segments (Bagchi and Mukerjee, 1983). Human intervention in terms of mini deep tube-welling again intensified the complicacy of sub-surface flow pattern.

Topographical height in this region is on an average of 16 m.a.s.l but due to strong irregular drafting of ground water, the water table has lowered down below $16 \mathrm{~m}$. i.e below Mean Sea Level (MSL). There are some points like Srikrishnapur, Bhawanandapur, Natungram, Aharinagar etc. within Hizole wetland, Ranagram, Indrahata etc. within Gokarna wetland area which register depth of water table $3 \mathrm{~m}$. - $6.5 \mathrm{~m}$. below MSL during pre-monsoon. As a result micro level irregular sub-surface flow is scarcely at parity with surface flow and this is not in conformity with the eco-hydrological character of the region (fig.7). The surface flow direction is on the average toward south and south-eastern directions. The creation of those sucking points below MSL may result in salt water incursion from the adjacent Bay of Bengal which is in close proximity to the study area. This may cause salt water incursion into the soil in the near future and if it persists could result in the occurrence of such sucking centres along stretch of the old deltaic zone of West Bengal.

Table: 2 Relational analysis between CI vs WT, TW vs CI and TW vs WT during different years.

\begin{tabular}{|l|l|l|l|l|l|l|}
\hline Year & $\begin{array}{l}\text { Crop } \\
\text { Intensity (CI) }\end{array}$ & $\begin{array}{l}\text { Water Table } \\
\text { (GWT) in m. }\end{array}$ & $\begin{array}{l}\text { No. of Mini } \\
\text { deep tube- } \\
\text { well (TW) }\end{array}$ & $\begin{array}{l}\text { 'r' } \\
\text { CI vs WT }\end{array}$ & $\begin{array}{l}\text { 'r' } \\
\text { TW vs CI }\end{array}$ & $\begin{array}{l}\text { 'r' } \\
\text { TW vs WT }\end{array}$ \\
\cline { 1 - 4 } $2000-01$ & 191.29 & 17.75 & 1950 & \multirow{2}{*}{0.972} & 0.977 & \multirow{2}{*}{0.999} \\
\hline $2003-04$ & 195.24 & 18.66 & 2144 & 2444 & & \\
\hline
\end{tabular}

Source: ADO office, PHE Dept., Electrical Office of Kandi and Gokarna. 


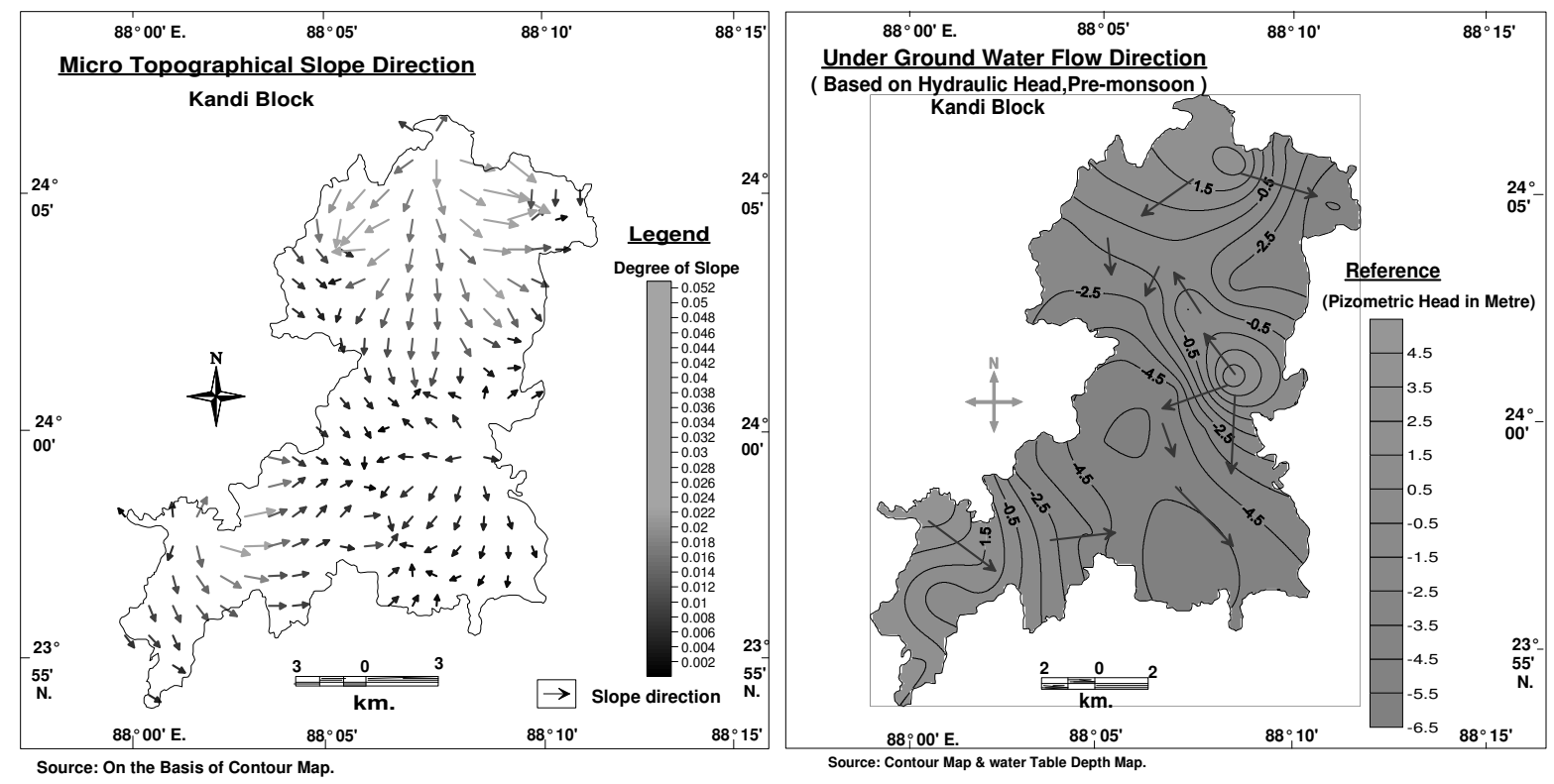

Fig.7 Topographical slope and groundwater flow directions in kandi Block

\section{Conclusion}

The findings from this study revealed that irregular sub-surface flow due to creation of numerous water sucking points at the mini deep tube-well centres. Due to intensive summer season culture as much as 2444 mini deeps with progressive way are drawing ground water. That's why ground water table have been slashed by $0.32 \mathrm{~m} . /$ year since 1968 to 2008 during summer but it is more higher (0.35 m./year between 2001-2008. During May, 1968 G.W.T. depth was 6.09 m. whereas it is almost $20.19 \mathrm{~m}$. during May, 2008. Rainy season's G.W.T. has also been lowered from near surface level before 43 years since present to almost about 12 meters at the present period (2007-08). Water balance analysis between water recharge and water discharge, showed there was $58.95 \times 10^{5}$ cubic meters water deficit just for summer period water draft. Spatial analysis shows that except Kumarsanda G.P. most of the other G.P. carry negative water balance. Highly positive relationship is found between no. of mini deep tube-well \& ground water table depth both in perspective of block level and micro spatial (gram panchayat) level. Here ' $r$ ' values (0.82-0.99) are significant in 0.01 level of confidence.Seasonal fluctuation of water table is so high $(5.66 \mathrm{~m}$. to $9.93 \mathrm{~m}$.) even in the beel areas that such problem may create arsenic threat in ground water. Both qualitative and quantitative threats of ground water abrasion may cause irrigational water scarcity and drinking water crisis. Before hundred and fifty years ago most of the wetlands were covered with large number of floral and faunal aggregation (Gastrell, 1860) but due to loss of areal extent of the wetland, water retention capacity, loss of permanency of water storage and change of land use (O'Malley, 1914), natural set of biodiversity of the wetland landscape has simplified and transmuted into fragile paddy ecosystem. And several species of reptiles, fishes, endemic birds, migratory birds, amphibians etc. have lost their safe shelter as well as faunal richness has abruptly changed unexpectedly.

\section{Recommendations}

The following recommendations are proposed foe wetland management in the area which include:

Change of land use can to some extent mitigate such ensuing threats of ground water scarcity. It is estimated that $63 \times 10^{4}$ to $72 \times 10^{4}$ litres of water is needed to sustain one hectare of cultivated paddy land during summer yielding profit of about Rs. 3000-3500. In place of summer paddy cultivation crops like onion, 
pulses, oil seeds, vegetables can be cultivated these will consume not greater than $7.2 \times 10^{4}$ to $12.6 \times 10^{4}$ litres of water and yield Rs. 2000 to 12000 . Therefore cultural change in land use by farmers will be hydrologically beneficial and economically remunerative $(\$ 1=$ about 48 rupees).

Trapped monsoon flood or rain water can be utilized for sustainable fish farming up to the next monsoon season. Structured use of one hectare of water logged unit for fish farming for about five to seven months can yield profit of about Rs. 18000 to 25000. Moreover, one hectare water logging unit having depth between $1.56 \mathrm{~m}$. to $2.36 \mathrm{~m}$. can retain water of about $70.65 \times 10^{5}$ to $10.62 \times 10^{6}$ litres of water which in turn can irrigate 65 to 150 hectares of pulses, onion, oil seeds. So cumulative profit of fishing and irrigation water is obviously far

\section{Reference}

Bagchi, K and Mukerjee, K.N. (1983). Diagnostic Survey of West Bengal(s), Dept. of Geography, Calcutta University, Pantg Delta \& Rarh Bengal; pp 17-19, 42-58.

Bugenyi, F.W.B. (2001). Tropical freshwater ecotones: their formation, function and use. Hydrobiologia 458: 33 - 43.

Bullock, A. and Acreman, M. (2003). The role of wetlands in the hydrologic cycle. Hydrology and Earth System Sciences, Vol. 7, No. 3, pp. 358-89.

Burke, L., Kura, Y., Kassem, K., Revenga, C., Spalding, M., and McAllister, D. (2001). Pilot Analysis of Global Ecosystems: Coastal Ecosystems. Washington, DC, World Resources Institute.

Chaturvedi, R.S. (1973). A Note on the Investigation of Ground Water Resources in Western Districts of Uttar Pradesh. Annual Report, U.P. Irrigation Research Institute. pp. 86-122.

Dagnachew, L., Vallet-Coulomb, C. and Gasse, F. (2003). Hydrological response of a catchment of climateand land use changes in Tropical Africa: case study South Central Ethiopia. Journal of Hydrology 275: 67 - 85.

Groombridge, B. and Jenkins, M. (1998). Freshwater biodiversity: A preliminary global assessment. WCMC Biodiversity Series No. 8.

IUCN (World Conservation Union) Water and Nature Initiative. Conservation International and Nature Serve. (2004). Global Amphibian Assessment. www.globalamphibians.org

- 2003a. Red List of Globally Threatened Species. Cambridge, United Kingdom. greater than the return due to present land use practices.

Timely supply of dam water through the rivers like Mayurakshi, Dwarka, can help a lot to serve the irrigation water during non-monsoon period and feeder channels should be reexcavated for free penetration of water between wetland units and Dwarka River. It will help to store water in the wetland.

Afforestation along river banks, embankments, fallow lands etc. also to some extent will energize the infiltration rate.

It is undoubtedly a climax period when deep contemplation for monotonous mono cropping imperatively be broken down and shifting of occupation (agriculture to other eco-friendly economic activities) is necessary to keep wetland landscape free from huge lop-sided population pressure and to establish the rationale of economic ecology.

Kumar, C.P. amd Seetapathi, P.V. (2002). Assessment of Natural Ground Water Recharge in Upper Ganga Canal Command Area; Journal of Applied Hydrology, vol. XV, no. 4, pp. 13-20.

O' Malley, L.S.S. (1997). Bengal District Gazetteers, Murshidabad, Govt. of West Bengal. pp. 22-24.

Owor, M., Muwanga, A. and Pohl, W. (2007). Wetland change detection and inundation north of lake George, Western Uganda using landsat Data. Afr.J.Sci \&Tech. 8: 94 -106.

Mistch-William, J., Gosselink James, G. (1986). Wetlands, New York, Van Nostrand Reinhold, Denny.

Sen, Satyakam (1970). The Importance of Drainage in Agriculture of West Bengal, A Publication of the Geographical Institute, Presidency College, Calcutta. pp. 80-81.

Siraj, S.M. (1995): Trinabhumi. P. 287.

Tenalem, A. (2002). Recent changes in the level of Lake Abiyata, main Ethiopian Rift. Hydrological Sciences 47(3): 493 - 503.

Tenalem, A. (2008). Hydrological system analysis and groundwater recharge estimation using semidistributed models and river recharge in the Meki River basin, Ethiopia. SINET: Ethiopian Journal of Science 31(1): $29-42$.

West Bengal District Gazetteer, (2003). Higher Education Division, West Bengal Government and Office of District Magistrate, Murshidabad District, West Bengal. pp. 17-24, 32-38. 